\title{
этнология
}

\section{«Люди ехали и верили: город будет!». К истории становления Элисты как города в 1928-1930 годах}

\section{Алтана Марковна Лиджиева ${ }^{1}$}

${ }^{1}$ Калмыцкий научный центр РАН (д. 8, ул. им. И. К. Илишкина, 358000 Элиста, Российская Федерация) аспирант, младший научный сотрудник

(iD) 0000-0003-3932-0354. E-mail: kulminova@gmail.com

(C) КалмНЦ РАН, 2020

(С) Лиджиева А. М., 2020

\begin{abstract}
Аннотация. Введение. Статья посвящена начальному периоду истории Элисты как города. Впервые делается попытка сравнения антропологических параметров городского пространства на первоначальном этапе истории города и в настоящее время. Цель статьи - рассмотреть первый, ключевой, этап становления и развития Элисты как центра Калмыцкой Автономной области. Основным материалом для анализа послужили документы Национального архива Республики Калмыкия. Memoдbl. Исследование проводилось с использованием исторического и структурнофункционального метода. Результаты и выводы. Автор приходит к выводу о том, что сохранение старых зданий до настоящего времени является репрезентацией собственной локальной памяти города. Показано, что важную роль в подобной репрезентации сыграла сохранность исторической архитектуры.

Ключевые слова: история, областной центр, Элиста, коллективная память, город, городское пространство, социальная память

Благодарность. Исследованиепроведено в рамках государственной субсидии - проект «Комплексное исследование процессов общественно-политического и культурного развития народов Юга России» (номер госрегистрации: АААА-А19-119011490038-5). Для цитирования: Лиджиева А. М. «Люди ехали и верили: город будет!». К истории становления Элисты как города в 1928-1930 годах // Монголоведение. 2020. № 4. C. 764-777. DOI: 10.22162/2500-1523-2020-4-764-777
\end{abstract}


UDC $572+294.3$

DOI: $10.22162 / 2500-1523-2020-4-764-777$

\title{
'People Would Set out Completely Convinced: There Will Be a City!': History of Transforming Elista into a City (1928-1930) Revisited
}

\author{
Altana M. Lidzhieval \\ ${ }^{1}$ Kalmyk Scientific Center of the RAS (8, Ilishkin St., 358000 Elista, Russian Federation) \\ Postgraduate Student, Junior Research Associate \\ (iD) 0000-0003-3932-0354. E-mail: kulminova@gmail.com
}

\author{
(C) KalmSC RAS, 2020 \\ (C) Lidzhieva A. M., 2020
}

\begin{abstract}
Introduction. The article deals with the early history of Elista as a city, and makes a first attempt to anthropologically compare urban space at the initial stage of the city's history to its current conditions. Goals. The paper examines the first and key stage in the formation and development of Elista as center of Kalmyk Autonomous Oblast. Materials. The bulk of analyzed sources are documents contained in the National Archive of the Republic of Kalmykia. Results. The work concludes that the preservation of old buildings to date is a representation of the city's local memory. As is shown, the preservation of historical architecture proved crucial to such a representation.
\end{abstract}

Keywords: history, regional center, Elista, collective memory, city, urban space, social memory, identity

Acknowledgements: The reported study was funded by government subsidy — project name 'Socio-Political and Cultural Development of South Russia's Peoples: Comprehensive Studies in Respective Processes' (state reg. no. AAAA-A19-119011490038-5).

For citation: Lidzhieva A. M. 'People Would Set out Completely Convinced: There Will Be a City!': History of Transforming Elista into a City (1928-1930) Revisited. Mongolian Studies (Elista). 2020. No. 4. Pp. 764-777. (In Russ.). DOI: 10.22162/2500-1523-2020-4764-777

\section{Введение ${ }^{1}$}

В истории Элисты как города в значительной степени отразились события социалистических преобразований в период Советской власти. Политические и общественные реформы 20-30-х гг. ХХ в. вносили крупные перемены в различные сферы повседневной жизни, идеологической борьбы и этничности, где каждый народ самоопределял себя в рамках новой единой национальной территории. Мартина Лёв, рассуждая о структуре собственной логики городов и их различий, отмечала, что «собственная логика каждого города не всегда объясняется только историей» [Собственная логика 2019: 45]. Изучение пространства, как справедливо замечает Ю. П. Шабаев, «неизбежно требует обращения к широкому культурному контексту, включая историю города и этнокультурную динамику территориального сообщества, с которым город непосредственно связан административными и иными отношениями» [Антропология города 2013: 12].

\footnotetext{
${ }^{1}$ В названии статьи использована цитата из [Ерымовский 1960: 19].
} 


\section{Монголоведение • Mongolian Studies • 2020 ๑ T. 12 • № 4}

Этот подход мы и выберем в роли элемента изучения, который, как мы надеемся, позволит приблизиться к «пониманию города» в тех трансформационных процессах, в которых живет современная городская культура сегодня. На сегодняшний день существуют лишь единичные научные работы, где так или иначе затрагиваются интересующие нас вопросы. Большинство исследований, посвященных Элисте, показывают вектор развития и становления города с позиций истории, ее диахронных и синхронных срезов, как, например, в работах И. С. Немичева [Немичев 1965; Немичев 1970; Немичев 1975; Немичев 1981].

Большое внимание образованию калмыцкой столицы в период социалистического строительства уделено в «Очерках истории Калмыцкой АССР» [Очерки истории 1970].

В краеведческих заметках И. В. Борисенко охарактеризовано хозяйственное освоение отдельных территорий города и села [Борисенко 1990]. Значимым вкладом в изучение города Элисты с позиций архитектуры стала монография Д. Б. Пюрвеева [Пюрвеев 1975]. В книге проанализированы этапы развития архитектуры Калмыкии, изменения за годы советской власти, когда калмыки полностью перешли на оседлый образ жизни.

В работе Э. П. Бакаевой и Ю. И. Сангаджиева исследуются проблемы закономерностей и способов перехода от традиционного кочевого жилища к стационарному и этнических приоритетов в калмыцкой национальной архитектуре [Бакаева, Сангаджиев 2005]. В ряде научных статей Э.-Б. М. Гучиновой была дана характеристика конструируемого имиджа, рассматривались национальные символы в пространстве города [Гучинова 2011; Гучинова 2013].

\section{Постановка задачи}

Автор ставит своей целью рассмотреть первый, ключевой, этап становления и развития Элисты как центра Калмыцкой автономной области.

\section{Основная часть}

V съезд Советов Калмыкии в 1925 г. принял решение перенести областной центр из Астрахани в Элисту, расположенную в районе наибольшего сосредоточения калмыцкого населения [Очерки истории 1970: 145]. Известно, что согласно «Декларации прав трудового калмыцкого народа», принятой I Общекалмыцким съездом Советов (2-9.07.1920), провозглашалось образование общенародной административно-хозяйственной Автономной области калмыцкого трудового народа в составе РСФСР [НА РК. Ф. 3. Оп. 2. Д. 925. Л. 351]. Изначально центральные калмыцкие учреждения находились в Астрахани, что продолжало дореволюционную традицию в XIX - начале XX в., когда аппарат управления калмыцким народом располагался в указанном губернском центре. В дореволюционный период власти использовали Астрахань как форпост для распространения своего «цивилизованного» влияния на «отсталых» кочевников: посылали в степь православных миссионеров, создавали школы для инородцев и др. В первые годы советской власти здесь готовили кадры партийных и советских служащих. Здесь выпускались первые газеты, журналы и книги. Астрахань была крупным центром рыбной промышленности, и сюда еще с дореволюционных времен из улусов стекались бедные калмыки на рыбные и соляные промыслы: «темно-бронзовые сыны степей шли на любую тяжелую работу - лямочниками, соленосами, гребцами. С угрюмыми лица- 


\section{Этнология и антропология}

ми, без песен, привычных русскому слуху, исполняли они свой неблагодарный труд» [Ерымовский 1960: 19].

Однако, по мнению делегатов V съезда Советов, поволжский город был слишком удален от большей части улусов, находился вне территории Калмыцкой автономной области и поэтому не мог быть ни административным центром, ни тем более центром развития экономики и культуры. Необходимо было создать новое общественное пространство, которое бы, по представлениям политической элиты Калмыкии советского периода, носило не символический, а национальный характер и могло отвечать новым вкусам социалистического строительства. Как отмечает И. С. Немичев, «Еще I общекалмыцкий съезд Советов в 1920 году дал наказ областному исполнительному комитету перевести центр автономии из Астрахани в Элисту» [Немичев 1965: 20-21]. Но проблемы социально-политической ситуации, критическая нехватка финансовых средств не давали возможности предпринять в те годы фактические шаги. Для пока еще неформализованной Элисты в форме населенного пункта власти принимают конкретные решения лишь во второй половине 1920-х гг.

29 апреля 1926 г. ВЦИК утвердил решение съезда и дал указание СНК РСФСР оказать Калмыцкому облисполкому необходимую помощь в строительстве нового города. 6 мая 1927 г. СНК РСФСР принял постановление о перенесении центра Калмыцкой автономной области из Астрахани в Элисту, считая первым годом строительства 1927 год [НА РК. Ф. 3. Оп. 2. Д. 925. Л. 351].

Идея строительства новой столицы была принята калмыцким населением с огромным воодушевлением. На калмыцком и русском языках было распространено обращение с призывом принять «деятельное участие» в строительстве, создавались комитеты по сбору добровольных пожертвований. Вокруг элистинского строительства была развернута пропагандистская кампания. В ней использовались основные положения, выдвинутые еще 6 мая 1927 г. на заседании СНК РСФСР в горячей речи председателя Калмыцкого облисполкома Эрдни-Ара Кекеева. Он заявил, что вопрос о городе в Калмыкии упирается в будущее Калмыцкой области, что нельзя ждать три-четыре года, пока произойдет общий экономический подъем Калмыкии, пока будут проведены железные дороги, что следует «не ждать, а самим помогать этому подъему» [НА РК. Ф. 3. Оп. 2. Д. 925. Л. 354].

Как будет выглядеть пространство будущего города, решали ведущие архитекторы страны: Б. А. Коршунов, Б. М. Великовский, И. А Голосов и др. В формировании архитектуры Элисты принимали активное участие представители Объединения архитекторов-конструктивистов - ОСА, возникшего в 1925 г. $^{2}$ в Москве и возглавлявшегося Б. А. Коршуновым [Пюрвеев 1975: 107-110].

24 мая 1927 г. Б. А. Коршунов выступает на президиуме Калмыцкого облисполкома с предварительными проработками и предложениями развития будущего города. Проектом планировки предлагалось разделить строительство на очереди в 5, 10 лет с зонами: промышленная, жилая, общественная, которые составлялись в соответствии с генпланом. По этому же проекту застройку

\footnotetext{
${ }^{2}$ В 1927 г. Объединение современных архитекторов (ОСА) было переименовано во Всероссийское объединение современных архитекторов (РОСА), но по-прежнему называлось ОСА [Хан-Магомедов 1996: 402].
} 


\section{Монголоведение • Mongolian Studies • 2020 ๑ T. 12 • № 4}

Элисты вводили в три очереди: 1-я очередь -1928-1932 гг., 2-я очередь 1932-1937 гг. и 3-я очередь - 1937-1952 гг. Расчетное количество населения города намечалось 10 тыс. человек [Пюрвеев 1975: 97].

Из этой перспективы исходили все последующие расчеты под жилье, общественные нужды. Новое мышление команды архитекторов в 1927-1930 гг. в действительности формировало новый облик города, где в значительной степени отражались идеи конструктивизма. Весьма важным, следуя логике подхода микроурбанизма, представляется и тот факт, что за основу при составлении генерального плана Элисты был взят эскизный набросок Б. Г. Джиринтеева, этнического калмыка, который вместе с инженером К. К. Клоссовским осуществил предварительную топосьемку территории под застройку. Особенность этого микрособытия, на наш взгляд, состоит в том, что при планировке и строительстве учитывались «особенности культуры как способа структурирования пространства» [Зукин 2018]. В этом смысле наглядным примером могут являться споры касательно места расположения будущего города.

Архивные источники сохранили сведения о дискуссии по этому вопросу. Так, одна часть калмыцких делегатов V съезда считала, что город должен находиться где-то недалеко от Волги, чтобы не уходить далеко в степь. В западной части области, говорили, нет дорог, нет перспективы для развития города. Другие считали, что город должен быть в самой глубине степи, в ее географическом центре: как раз в восточных районах, где преобладают пески, солончаки, отсутствует вода и сенокосы, нет перспектив не только для роста города, но и для развития хозяйства, и совершенно другое значение для области имеют западные районы, район села Элисты - в этих районах сконцентрировано 2/3 калмыцкого населения, 78 \% скота — основного богатства области; посевная площадь сосредоточена в западных районах [НА РК. Ф. 3. Оп. 2. Д. 925. Л. 351].

Существовала и третья точка зрения - перенести город в село Башанту. Вероятней всего, предложение было связано с тем, что село Башанта, образованное в 40-х г. XIX в. как ставка Большедербетовского улуса, после Октябрьской революции было перспективным, с точки зрения развития, районным центром.

Из трех вариантов был выбран второй, и столицу решено было учредить в центре степи. В решении о выборе места будущего города ключевым критерием стал территориальный фактор. Делегаты, принимавшие участие в решении данного вопроса, также посчитали, что районы Элисты были пригодны к обработке земли и являлись одним из центров скотоводства - основного хозяйства калмыков. Благоприятные условия существующего села должны были поспособствовать быстрому росту нового города.

Обосновывая перспективу развития столицы, Б. А. Коршунов указывал, что первоначальный толчок росту города даст объединение в одних границах будущего города и села Элисты, затем скажется то обстоятельство, что Элиста находится на пересечении трех магистралей - на Ставрополь, Астрахань, Волгоград, что обеспечит возможность проведения железных дорог [Немичев 1965]. При сборе материалов мы встречали упоминания об имеющемся проекте проведения железных дорог [НА РК. Ф. 3. Оп. 2. Д. 1073. Л. 163], но более подробных сведений источники не указали. Остается лишь признать, что замысел архитектора так и остался нереализованным. 


\section{Этнология и антропология}

По решению облисполкома в новой столице Калмыкии в первую очередь строились здания для административных органов: «Mbl, ответработники калмыки, готовы и вынуждень будем перейти и работать даже в кибитках, лишь бы построчть помещения для аппарата и самых необходимых сотрудников» [НА РК. Ф. 3. Оп. 2. Д. 925. Л. 351].

Стоит отметить, что в первые годы строительства ввиду нехватки стационарных административных зданий, клубов, школ власти обращались к кибиткам. Кибитки (калм. гер) разрешали проблему острой нужды в производственных помещениях. Здесь мы видим еще одно проявление универсальности традиционного жилища. Таким же образом известные в истории Калмыкии «красные кибитки» «использовались под клубы, школы и другие общественные учреждения» [Пюрвеев 1975: 105-106]. Таким образом, кибитка в переходное время служила помещением для организаций до постройки общественных зданий, что, в свою очередь, свидетельствует о ее многофункциональности и иллюстрирует обращение к традиционным формам в новых городских условиях жизни.

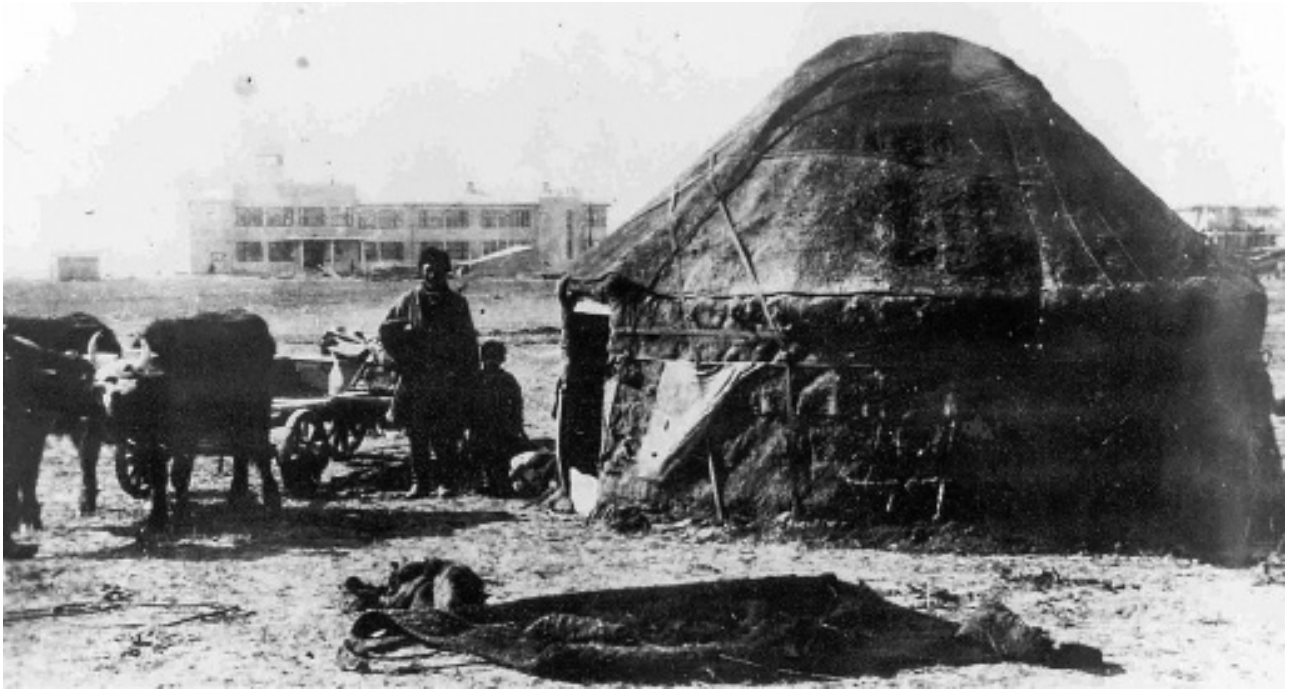

Фото 1. Калмыцкая кибитка. 1928 г.

[Photo 1. Kalmyk yurt. 1928]

Для подготовки местных кадров рабочих были созданы курсы, на которых обучали строительным профессиям. Среди окончивших эти курсы были А. Садовников, И. Букатин, С. Комбиров и др.

Многих строителей и инженеров направляли на строительство Элисты партийные власти г. Астрахани. Так, молодожены Козорез были направлены в Элисту в 1929 г. Братья Харченко прибыли из Ростовской области, А. Кибало и братья Логвиненко - из Украины; И. Скляров - из Воронежа. Большую помощь кадрами, стройматериалами, продовольствием оказывали Нижне-Волжский край, затем Сталинградский край${ }^{3}$, в состав которых Калмыцкая область входила в 1928-1935 гг. [Степное чудо 2015: 38].

${ }^{3}$ Постановлением ВЦИК от 10 января 1934 г. Нижневолжский край был разделен на Сталинградский и Саратовский края [История административно-территориального 2012: 7]. 


\section{Монголоведение • Mongolian Studies • $2020 \bullet$ T. 12 • № 4}

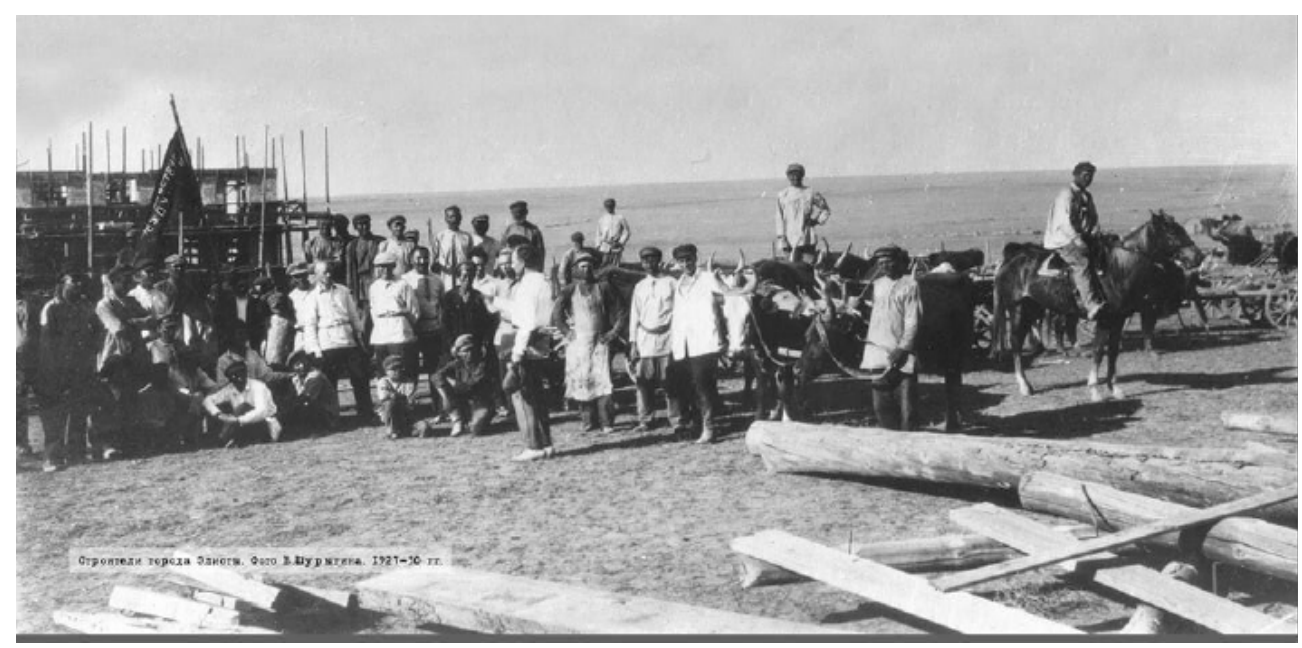

Фото 2. Строители города Элисты. Конец 1930-х гг. Фото В. Шурыгина.

[Photo 2. Builders of Elista City. Late 1930s. Photo by V. Shurygin]

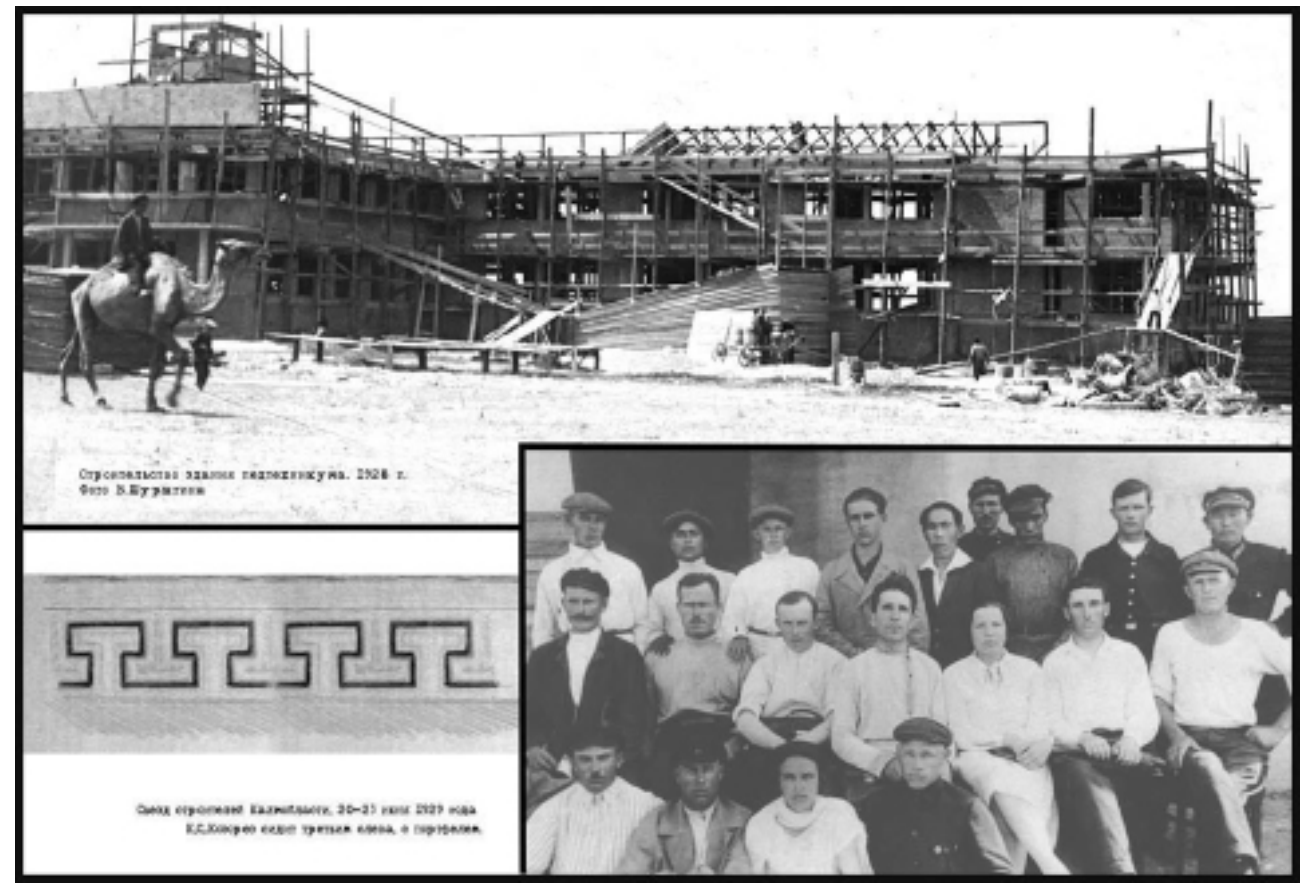

Фото 2. Строители города Элисты. Конец 1930-х гг. Фото В. Шурыгина.

[Photo 2. Builders of Elista City. Late 1930s. Photo by V. Shurygin]

Фото 3. Вверху: Строительство здания педтехникума. 1930 г.

Справа: участники Съезда строителей Калмобласти. 20-23 июня 1929 г.

Фото В. Шурыгина

[Photo 3. At the top: Construction site of Teachers College. 1930.

On the right: participants to Congress of Kalmyk Oblast's Builders.

June 20-23, 1929.

Photo by V. Shurygin] 


\section{Этнология и антропология}

Строительство носило сезонный характер. «На зиму строительство замирало, с весны вновь все приходило в движение: приезжали рабочие, ставили кибитки и курени, начинали расти здания» [Немичев 1970: 25].

Жилые и общественные сооружения возводились не выше двух-трех этажей с расчетом, чтобы их высота не превышала крон окружающих деревьев, укрывающих от знойного солнца [Пюрвеев 1975: 92]. Наличие в районе Элисты сырья для производства некоторых строительных материалов сокращало поставки стройматериалов заказных. На месте было организовано производство стеновых материалов, таких как камышебетон, кирпич «рекс», красный кирпич. Кирпич изготовляли на старом заводе, который находился на западной окраине Элисты [Пюрвеев 1975: 98]. Для производства кирпича «рекс» и камышебетона в юго-восточной части города был построен новый завод на территории совхоза «Элистинский» (ныне помещение строительного магазина по ул. Ленина, 91А). Здания строили на глиняном растворе, так как весь цемент шел на формирование «рекса».

Можно сделать вывод, что уже на первом этапе развития в связи с массовым строительством в городе развивалась промышленность как один из способствовавших градообразованию факторов. К концу 1927 г. было возведено пять жилых домов, первые три из которых построили высотой в один этаж, остальные - в два этажа (ныне эти здания разрушены), автогараж (на его месте ныне стоит корпус № 1 гостиницы «Элиста»). Кроме того, в краткие сроки были построены амбулатория (сгорела во время войны, на ее месте построен роддом по ул. Ленина, ныне - перинатальный центр), педтехникум (разрушен во время войны, на его месте сегодня расположено центральное отделение «Почты России» по ул. Сусеева), - строительство этих зданий было завершено в 1928 г. [Немичев 1965: 23].

Начиная с лета 1927 г. в Элисту переезжают отделы облисполкома. В 1928 г. переехали остальные отделы, органы управления и редакции газет. По этому поводу в последнем астраханском номере газеты «Красная степь» был опубликован придуманный редакцией юмористический шарж: «работники областного исполкома, взгромоздив на плечи свое здание и держа за повод верблюда, шагали по пескам и вскоре распрощались с Астраханью» [Ерымовский 1960: 16].

После переезда в Элисту областных учреждений строительство города значительно активизировалось. В 1929-1930 гг. были построены типография, общежитие педтехникума, школа-десятилетка (взорвана фашистскими оккупантами в 1942 г.), госбанк, почта, пожарное депо, жилые дома [Элиста 1965: 24].

Центр автономии рос, однако официально Элиста продолжала числиться в списке сельских поселений. Калмыцкий облисполком настойчиво ходатайствовал о преобразовании Элисты в город. 10 марта 1930 г. Президиум ВЦИК принимает постановление «Село Элисту Калмыцкой Автономной области преобразовать в город, объединив его со вновь строящимся городом того же наименования» [НА РК. Ф. 3. Оп. 2. Д. 1339. Л. 56].

Что не изменилось с 1930-х гг., так это наше понимание впечатлений, образности, следа или отражения, оставляемых в сознании человека предметами и явлениями внешнего мира. Многие известные писатели, посетившие в те 


\section{Монголоведение • Mongolian Studies • 2020 ๑ T. 12 • № 4}

годы Элисту, искали и видели в ней экзотику. Константин Ерымовский, бывший в те годы журналистом газеты «Улан теег» ('Красная степь'), вспоминал, какой видел столицу Калмыкии летом 1927 г.: «В степную столицу переезжали сотни людей, учреждения, склады», «перед нами расстилалась степь, но уже обжитая - с ровной дорогой, частыми путниками и автомашинами. На одном из бугров одиноко и гордо возвышалось огромное белое здание. Вблизи раскинулись несколько темных кибиток. А прямо перед нами открытый автомобильный гараж с примкнувшими к нему строениями $<\ldots>$ К механическим машинам у кочевников сразу возникло чувство доверия. Они складывали о них песни, восхваляли их силу и даже „масть“. Животные, которые прежде боялись шума двигателя, впоследствии спокойно отходили в сторону, вдыхая запах бензина...» [Ерымовский 1960: 37].

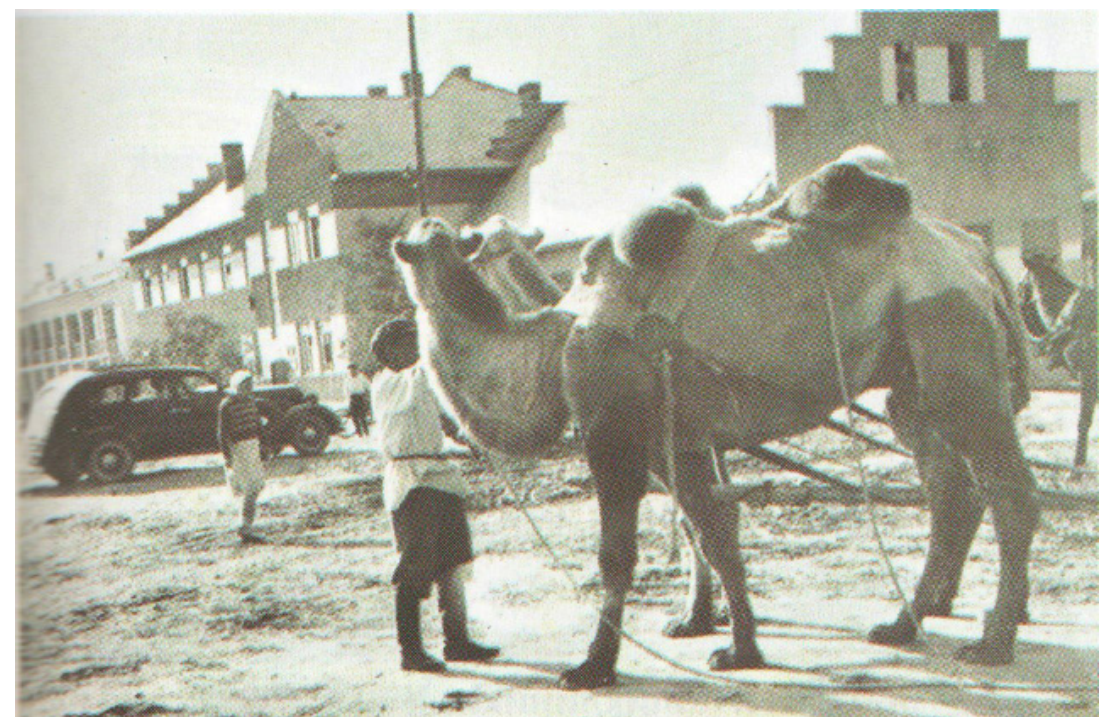

Фото 4. Элиста. 1932 г.

[Photo 4. Elista. 1932]

Облик начинающего складываться города был характерен своей яркой индивидуальностью и единством. В 1935 г. Калмыцкая автономная область была образована в Калмыцкую Автономную Советскую Социалистическую Республику, а Элиста стала столицей Калмыцкой АССР.

С момента переезда областных учреждений фактически начал формироваться городской ландшафт (общественные здания, жилые дома), который в настоящее время воплощается как материальные «места памяти». Понятие «места памяти» введено в научный оборот исследователем Пьером Нора. Одним из главных аспектов в концепции французского историка было то, что термин «места памяти» не всегда подразумевает только географическое наполние. В ряде работ ученый исследовал символические особенности национального французского флага, государственного гимна Франции «Марсельеза», библиотек, архивов, а где-то и известного во всем мире французского «Каберне Совиньон». «Места памяти» П. Нора определяет «как места, на которых складывается память» [Нора 1999: 35-38]. Концептуальность данного смысла опреде- 


\section{Этнология и антропология}

ляет его применимость и к особенностям современного городского ландшафте Элисты. Так, многие места и пространства в Элисте, которые сегодня считаются культурными объектами и городскими достопримечательностями, обрели этот статус не сразу. Некоторые из них, например краеведческий музей (1931 г., здание поныне стоит в г. Элисте в пер. Театральном $\left.{ }^{4}\right)$, изначально являлись культурным пространством. Об этом и сегодня говорит число посетителей музея, многие из которых оставили в книге записей свои отзывы, советы, пожелания, которые помогали сотрудникам музея улучшить его работу.

Другие объекты, как, например, Дом Советов, были простроены в качестве репрезентации централизованной власти. Пространство центра Элисты акцентировалось зданием Дома Советов. Проект Дома Советов, разработанный архитектором И. А. Голосовым (в соавторстве с архитектором Б. Миттельманом и инженером С. Прохоровым), был представлен для участия в московском конкурсе «на проекты Домов Советов». Разработка проектов началась в середине 1920-х гг., как отмечает С. Хан-Магомедов, когда в республиках и областях развернулось строительство зданий для новых органов народной власти [Хан-Магомедов 1986: 41].

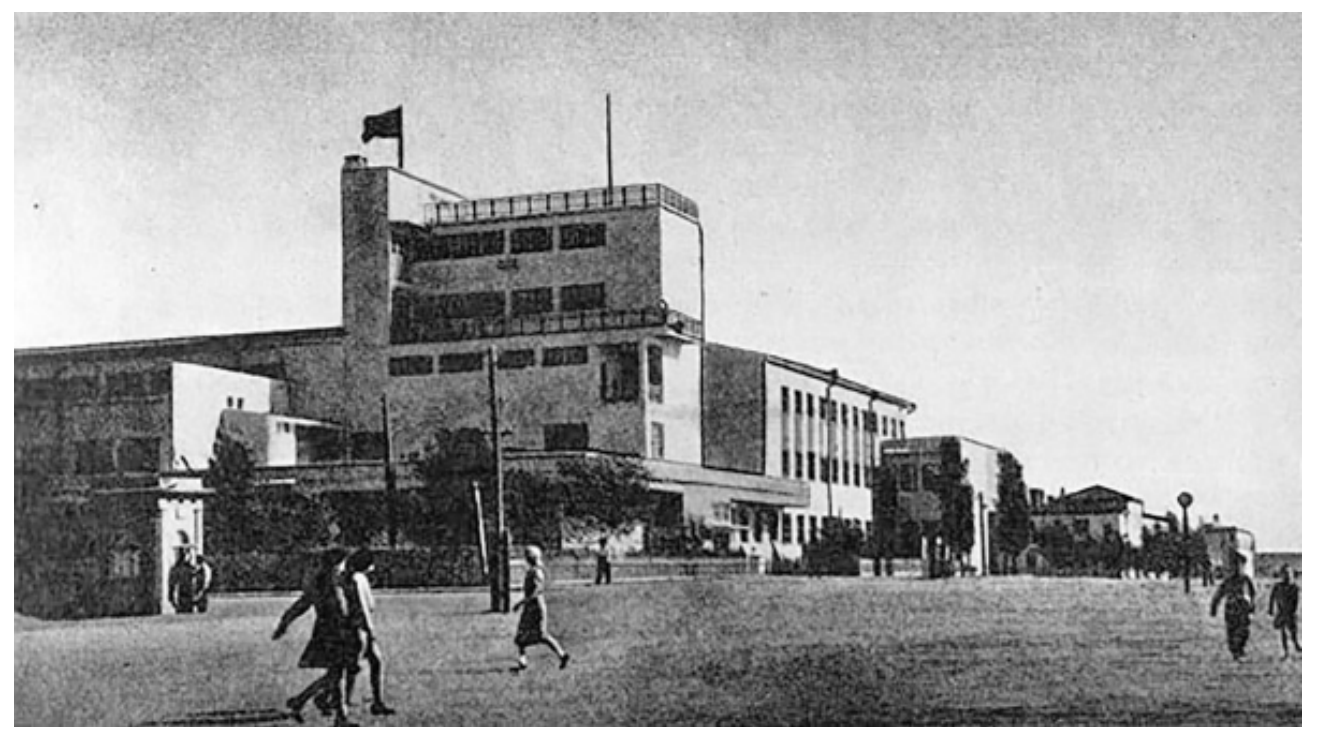

Фото 5. Дом Советов. Общий вид

[Photo 5. House of Soviets. Main view]

И. А. Голосов проектировал здания не только в Элисте, но и в других городах. Так, сохранившиеся до настоящего времени Дом Советов в Хабаровске (1928), Краевой Дом Советов в Ростове-на-Дону (1935) и др. также могут рассматриваться в качестве репрезентации централизованной власти, поскольку были созданы для размещения партийных и советских органов. Архитектор И. А. Голосов творил в стиле конструктивизма - авангардного направления искусства того периода, главными отличительными особенностями которого

\footnotetext{
${ }^{4}$ Калмыцкий республиканский краеведческий музей ныне называется Национальный музей Республики Калмыкия имени Н. Н. Пальмова, новое здание музея построено в г. Элисте по ул. Джангара.
} 


\section{Монголоведение • Mongolian Studies • $2020 \bullet$ T. 12 • № 4}

являлись строгость форм, отражающих конструктивное решение, а также геометризм и монолитность форм. Конструктивисты главное внимание уделяли функциональному значению здания, которое должно было определить его конструкцию. Не стал исключением и Дом Советов в Элисте.

Здание Дома Советов выделено в окружающей застройке. Архитектурная композиция здания замкнутая. Как отмечает Д. Б. Пюрвеев, «композиция наиболее соответствовала местным климатическим условиям: П-образное в плане расположение трехэтажных корпусов способствовало затемнению дворового пространства» [Пюрвеев 1975: 110].

В проекте Дома Советов И. А. Голосов реализовал замысел генерального плана Элисты - связал главные магистрали города, организовав административную площадь с памятником В. И. Ленину в центре. Как пишет С. Хан-Магомедов, «Дом правительства определил облик центра Элисты» [Хан-Магомедов 1986: 31]. Несмотря на то, что в послевоенный период в процессе восстановления разрушенного здания оно было в незначительной степени изменено, а в конце 1980-х гг. фасадная часть облицована розовым туфом, здание Дома Советов (ныне первый корпус Калмыцкого госуниверситета им. Б. Б. Городовикова) по-прежнему является одним из коммеморативных мест, константой, сохраняющей визуальное прошлое города.

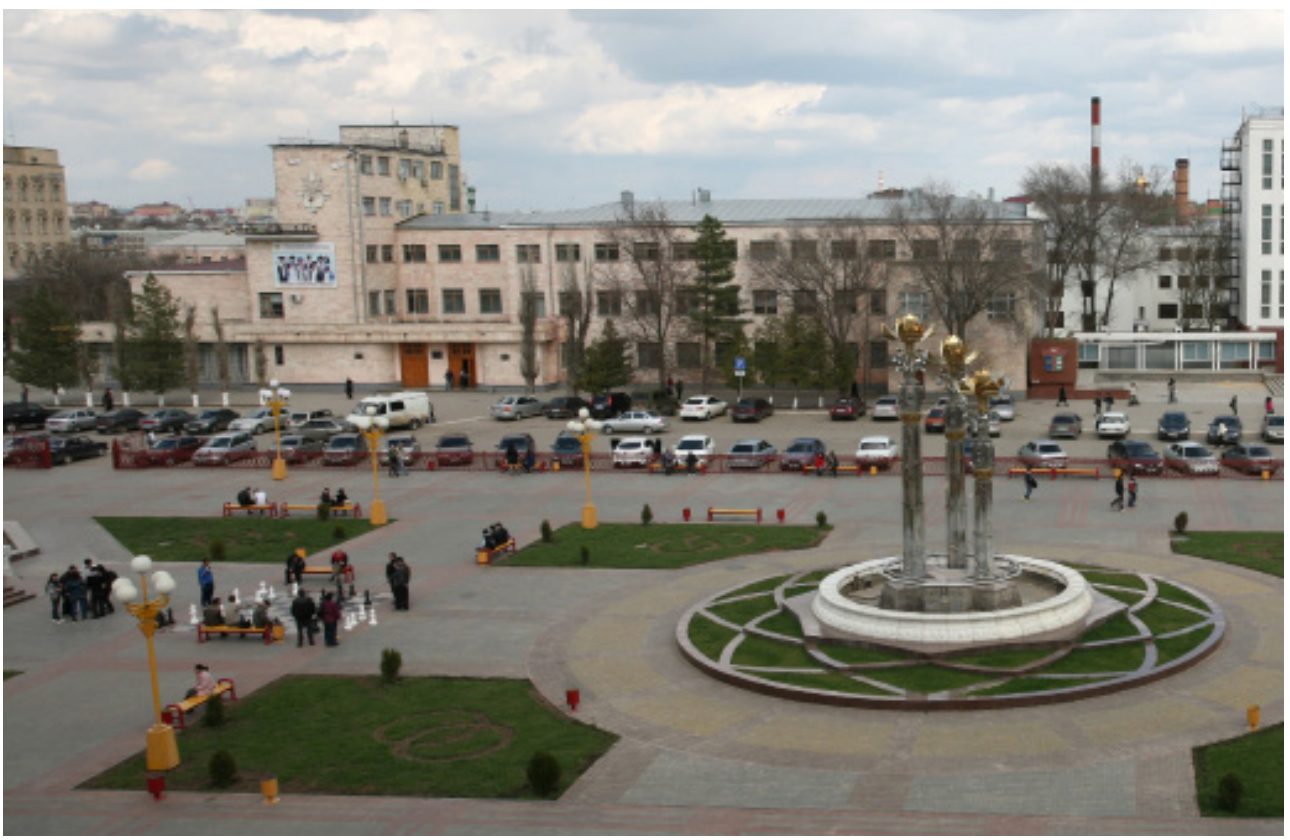

Фото 6. Элиста. Площадь Ленина.

В глубине - здание первого корпуса Калмыцого государственного университета им. Б. Б. Городовикова (в прошлом Дома Советов). 2009 г. Фото Н. Бошева

[Photo 6. Elista. Lenin Square.

At the back - Headquarters building of the Gorodovikov Kalmyk State University's (former House of Soviets). 2009. Foto by N. Boshev]

Визуальные проявления локальной памяти отражаются и в других районах города. Примером может служить расположенное по ул. Лениа к западу от 


\section{Этнология и антропология}

центра города здание, известное среди горожан как Красная школа. Из истории города известно, что здание было построено в 1907 г. на общественные средства как улусная школа-интернат для мальчиков. Строилось оно из красного кирпича, эта примета закрепилась в названии. Красная школа состояла из двух классных комнат, одного зала, квартиры для учителя и санитарной комнаты. В настоящее время здание сохранилось почти в первозданном виде.

Для жителей города здание школы - память о первых учителях Калмыкии, символ народного просвещения.

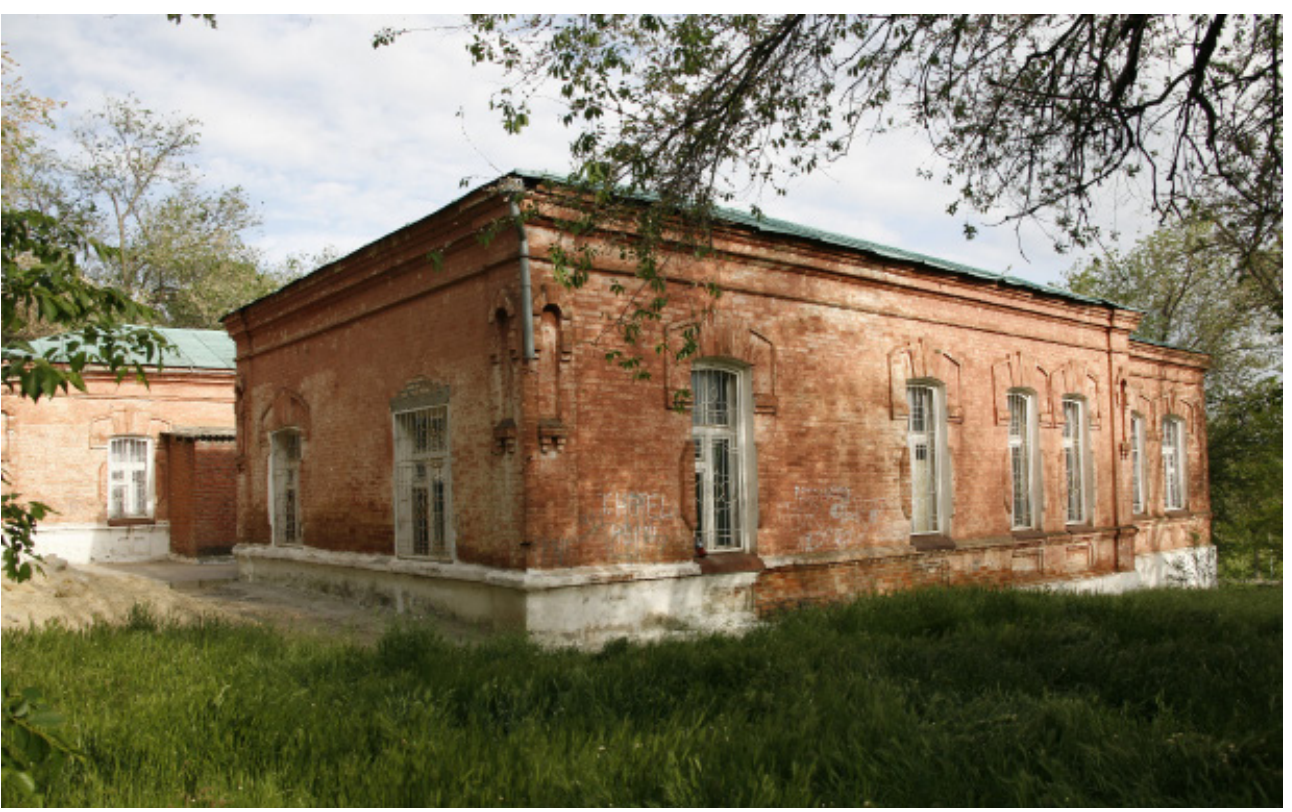

Фото 7. Элиста. Красная школа по улице Ленина, 201а. 2010 г. Фото Н. Бошева [Photo 7. Red School (201a, Lenin St., Elista). 2010. Foto by N. Boshev]

\section{Заключение}

Перевод центра Калмыцкой Автономной области в 1927-1930 гг. в г. Элисту положил начало строительству степного города. На первом, ключевом этапе становления и развития Элисты как города формируется общее городское пространство, строятся общественные здания, которые в настоящее время считаются объектами исторической архитектуры. Сохранение и функционирование сегодня зданий, построенных в 1930-е гг., которые прочно закреплены и отражены в современном городском пространстве, являются иллюстрацией собственной памяти города. Приводимые в работе архивные данные позволяют передать атмосферу повседневной жизни, энтузиазм людей, вдохновленных идеями созидания. Первый этап формирования облика столицы Калмыкии ознаменовал начало создания нового пространства. К концу 1930-х гг. столица Калмыкии - Элиста, строящаяся в самом центре калмыцкой степи, объединила вокруг себя единомышленников и стала местом экономической, политической и культурной жизни Калмыцкой автономной области. 


\section{Источники \\ НА РК — Национальный архив Республики Калмыкия \\ Sources}

National Archive of the Republic of Kalmykia.

\section{Литература}

Антропология города 2013 - Антропология города. Вып. 1: Культурные символы и образы в городском пространстве. Этничность и городская идентичность / под ред. Ю. П. Шабаева, И. Л. Жеребцова. Сыктывкар: Институт ЯЛИ Коми НЦ УрО РАН, 2013. $192 \mathrm{c}$.

Бакаева, Сангаджиев 2005 - Бакаева Э. П., Сангаджиев Ю. И. Культура жилища: этнические и современные приоритеты у калмыков. Элиста: АПП «Джангар», 2005. $196 \mathrm{c}$.

Борисенко 1990 - Борисенко И. В. Времен минувших отраженье: краеведческие заметки о Калмыкии. Элиста: Калм. кн. изд-во, 1990. 175 с.

Гучинова 2011 - Гучинова Э.-Б. М. Встречный ориентализм // Антропология социальных перемен. Исследования по социально-культурной антропологии: сб. ст. / отв. ред. Э.-Б. Гучинова, Г. А. Комарова. М.: РОССПЭН, 2011. С. 464-480.

Гучинова 2013 - Гучинова Э.-Б.М. Элиста: национальные символы в пространстве города // Антропология города. Вып. 1: Культурные символы и образы в городском пространстве. Этничность и городская идентичность. Сыктывкар: Институт ЯЛИ Коми НЦ УрО РАН, 2013. С. 43-65.

Ерымовский 1960 - Ерымовский К. Степные были: очерки, рассказы. Элиста: Калмиздат, 1960. 255 с.

Зукин 2018 - Зукин Ш. Культуры городов. 2-е изд. М.: Новое литературное обозрение, 2018. 424 с.: ил. (серия Studia Urbanica)

История административно-территориального 2012 - История административно-территориального деления Сталинградского (Нижневолжского) края. 1928-1936 гг.: справочник / сост. Д. В. Буянов, Н. С. Лобчук, С. А. Норицына. Волгоград: Волгоградск. науч. изд-во, 2012. 575 с.

Немичев 1965 - Немичев И. С. Краткий очерк истории Элисты (1865-1943 гг.) // Элиста. 100 лет. Прошлое. Настоящее. Будущее. Элиста: Калмиздат, 1965. С. 3-32.

Немичев 1970 - Немичев И. С. Город Степной (Элиста) и районы Калмыкии в период четвертой и пятой пятилеток (1946-1956 гг.) // Ученые записки Калмыцкого НИИЯЛИ. Вып. 9. Элиста, 1970. С. 179-219.

Немичев 1975 - Немичев И. С. История города Элисты - столицы Калмыцкой АССР (1928-1970 гг.): дис. ... канд. ист. наук. Элиста, 1975. 203 с.: ил.

Немичев 1981 - Немичев И. С. Роль города Элисты в консолидации Калмыцкой АССР // Исследования по исторической географии Калмыцкой АССР. Элиста: КНИИИФЭ, 1981. С. 121-126.

Нора 1999 - Нора П. Проблематика мест памяти // Франция-память / П. Нора [и др.]. СПб.: Изд-во С.-Петерб. ун-та, 1999. С. 17-50.

Очерки истории 1970 - Очерки истории Калмыцкой АССР: эпоха социализма. М.: Наука, 1970. 432 с.

Пюрвеев 1975 - Пюрвеев Д. Б. Архитектура Калмыкии. М.: Стройиздат, 1975. 183 с.

Собственная логика 2019 - Собственная логика городов: новые подходы к урбанистике: колл. моногр. / отв. ред. Х. Беркинга и М. Лёв; пер. с нем. К. Левинсон. 3-е изд. М.: Новое литературное обозрение, 2019. 424 с. : ил.

Степное чудо 2015 - Элиста: 150 лет. В 2 кн. Кн. 1. Степное чудо - Элиста. Элиста: Изд. дом «Герел», 2015. 95 с.

Хан-Магомедов 1986 - Хан-Магомедов С. О. Архитектор Илья Голосов (Пионеры советской архитектуры). М.: Знание, 1986. 62 с. 


\section{Этнология и антропология}

Хан-Магомедов 1996 - Хан-Магомедов C. О. Архитектура советского авангарда. Книга 1: Проблемы формообразования. Мастера и течения. М.: Стройиздат, 1996. $709 \mathrm{c}$.

Элиста 1965 - Элиста. 100 лет: прошлое, настоящее, будущее. Элиста: Калм. кн. издво, 1965. $127 \mathrm{c}$.

\section{References}

100 Years of Elista: Past, Present, Future. Elista: Kalmizdat, 1965. 127 p. (In Russ.)

Berking H., Löw M. (eds.) Internal Logic of Cities: New Approaches to Urban Studies. Joint monograph. K. Levinson (transl.). $3^{\text {rd }}$ ed. Moscow: Novoe Literaturnoe Obozrenie, 2019. 424 p. (In Russ.)

Buyanov D. V. et al (comps.) Stalingrad (Lower Volga) Krai: History of Administrative (Territorial) Division: 1928-1936. Reference book. Volgograd: Volgograd Science Publ., 2012. 575 p. (In Russ.)

Bakaeva E. P., Sangadzhiev Yu. I. Culture of Dwelling: Ethnic and Contemporary Priorities of Kalmyks. Elista: Dzhangar, 2005. 196 p. (In Russ.)

Borisenko I. V. Glimpses of the Past: Essays on Kalmykia's History and Lore. Elista: Kalmyk Book Publ., 1990. 175 p. (In Russ.)

Elista: 150 Years. In 2 vols. Vol. 1: Elista - a Miracle in the Steppe. Elista: Gerel, 2015. 95 p. (In Russ.)

Erymovsky K. True Stories of the Steppe: Essays, Short Novels. Elista: Kalmizdat, 1960. 255 p. (In Russ.)

Guchinova E.-B. M. Elista: ethnic symbols in urban environment. In: Shabaev Yu. P., Zherebtsov I. L. (eds.) Anthropology of the City. Vol. 1: Cultural Symbols and Images in Urban Environment. Ethnicity and Urban Identity. Syktyvkar: Institute of Language, Literature and History (Komi Scientific Center of Ural Branch, RAS), 2013. Pp. 43-65. (In Russ.)

Guchinova E.-B. M. Reciprocal Orientalism. In: E. B. Guchinova, G. A. Komarova (eds.) Anthropology of Social Changes: Studies in Sociocultural Anthropology. Coll. papers. Moscow: ROSSPEN, 2011. Pp. 464-480. (In Russ.)

Kalmyk ASSR: Historical Essays. Socialist Era. Moscow: Nauka, 1970. 432 p. (In Russ.)

Khan-Magomedov S. O. Architect Ilya Golosov (Pioneers of Soviet Architecture). Moscow: Znanie, 1986. 62 p. (In Russ.)

Khan-Magomedov S. O. Soviet Avant-Garde Architecture. Vol. 1: Issues of Structural Morphology. Masters and Trends. Moscow: Stroyizdat, 1996. 709 p. (In Russ.)

Nemichev I. S. Elista - Capital of the Kalmyk ASSR: History of the City, 1928-1970. Cand.Sc. (history) thesis. Elista, 1975. 203 p. (In Russ.)

Nemichev I. S. Elista and its role in the consolidation of the Kalmyk ASSR. In: Kalmyk ASSR: Studies in Historical Geography. Elista: Kalmyk Research Institute of History, Philology and Economics, 1981. Pp. 121-126. (In Russ.)

Nemichev I. S. Elista: a brief historical essay, 1865-1943. In: 100 Years of Elista: Past, Present, Future. Elista: Kalmizdat, 1965. Pp. 3-32. (In Russ.)

Nemichev I. S. Stepnoy (Elista) City and Kalmykia's districts during the Fourth and Fifth five-year plans: 1946-1956. In: Kalmyk Research Institute of Language, Literature and History: Scholarly Notes. Vol. 9. Elista, 1970. Pp. 179-219. (In Russ.)

Nora P. Problematique of memory places. In: P. Nora et al. France-Memory. St. Petersburg: St. Petersburg University, 1999. Pp. 17-50. (In Russ.)

Pyurveev D. B. Architecture of Kalmykia. Moscow: Stroyizdat, 1975. 183 p. (In Russ.)

Shabaev Yu. P. , Zherebtsov I. L. (eds.) Anthropology of the City. Vol. 1: Cultural Symbols and Images in Urban Environment. Ethnicity and Urban Identity. Syktyvkar: Institute of Language, Literature and History (Komi Scientific Center of Ural Branch, RAS), 2013. 192 p. (In Russ.)

Zukin Sh. Urban Cultures. $2^{\text {nd }}$ ed. Moscow: Novoe Literaturnoe Obozrenie, 2018. 424 p. (In Russ.) 